\title{
The Lotus Garland (padmamālā) and Cord of Power (śaktitantu): The Brahmayāmala's Integration of Inner and Outer Ritual
}

\author{
Shaman Hatley
}

The significance of the Brahmayāmala to the history of Śaivism was first identified by Alexis Sanderson (1988), who was gracious enough to read a section of this voluminous text with me at Oxford, in 2004, at an early stage of my doctoral research. This was a formative professional experience, and I remain touched by his generous hospitality towards me as an unknown visiting student. In the present essay, I revisit a particular thread which emerged from these reading sessions: the śaktitantu or śaktisūtra, the "thread" (tantu) or "cord" (sūtra) of divine power (śakti). This is a technical term of ritual distinctive to the Brahmayāmala to which Professor Sanderson first drew my attention. Inquiry into the Cord of Power leads me to examine the ways in which the Brahmayamala (hereafter BraYā) integrates meditational discipline with the somatic performance of ritual, and to query its understanding of the category yoga.

In chapter 15 of the Tantrāloka, Abhinavagupta invokes the authority of the BraYā concerning the inseparability of "external" (bāhya) and "inner" or "internal" (adhyātma) worship. The passage (15.43cd-44) reads as follows in the printed (Kashmir Series of Texts and Studies) edition:
nādhyātmena vinā bāhyaṃ nādhyātmam bāhyavarjitam ||43\|
siddhyej jñānakrìyābhyām tad dvitīyam samprakāśate |
śrībrahmayāmale deva iti tena nyarūpayat $\|44\|$

The fourth verse-quarter (44b) is problematic; following the commentator Jayaratha, ${ }^{1}$ the passage might be interpreted as meaning,

"Not without the inner (adhyātma) would the outer succeed, nor the inner devoid of the outer. The second [i.e. the inner] manifests through

1 Tantrālokaviveka ad 15.43c-44: tad dvitīyam iti adhyātmalakṣaṇam, " the second one' means 'characterized by being inner (adhyātma)'." 
both gnosis and ritual action" - the Lord has explained accordingly in the revered Brahmayāmala.

Both the sense and syntax appear doubtful, however. On the grounds of coherence, it seems significantly better in $44 \mathrm{~b}$ to read tad dvitayam ("that pair [of inner and outer]") for tad dvitĩyam ("the second one"), an emendation suggested by Harunaga Isaacson. ${ }^{2}$ In this case the passage might be interpreted as follows:

"Not without the inner (adhyätma) would the outer succeed, nor the inner devoid of the outer. That pair [of inner and outer] manifests through gnosis and ritual action, [respectively]" - the Lord has explained accordingly in the revered Brahmayāmala.

Thus it seems that Abhinavagupta places the dichotomy of outer (bāhya) and inner (adhyātma) worship in correlation with that of kriyā and jñāna: ritual action and gnosis, respectively. This accords with his remarks prefacing citation of the $B r a Y \bar{a}$, which clarify that the performative acts of ritual are valuable only as ancillaries to śivābhimānatā, conviction of one's identity with Śiva. This inner conviction alone, a form of knowledge, is the real means of liberation. ${ }^{3}$

One need not follow Abhinavagupta entirely in reading the BraYä's dichotomy between 'inner' and 'outer' processes in terms of gnosis and ritual: his source scripture draws no such distinction overtly. Nonetheless, Abhinavagupta's selection of the Brahmāyamala is by no means contrived, for in invoking the text thus he highlights a premise central to its systems of practice: the integration of internal and external ritual processes, which mirror each other closely.

Although many of Abhinavagupta's citations of the BraYā may be identified precisely, ${ }^{4}$ in this case the passage he had in mind remains uncertain. BraYā 87.140 is perhaps the strongest candidate:

2 Personal communication, 2003.

3 Tantrāloka 15.42-43b: śivābhimānitopāyo bāhyo hetur na mokșadah | śivo 'yam śiva evāsmūty evam ācāryaśisyayoh || hetutadvattayā dārdhyābhimāno mocako hy anoh | ("Conviction of one's identity with Śiva is the means; no external cause bestows liberation. 'He is Śiva, and I am nothing but Śiva': [in the rite of initiation,] this firm conviction of the guru and disciple is indeed what liberates a soul, by way of [the guru's conviction] being the cause and [the disciple's] the effect (? hetutadvattayā)").

4 See Hatley 2018, Appendix B. 


\section{ādhyātmañ cintayed bāhyam bāhyam adhyātmikām tathā | cakre samānabhāvena tato vinyāsam ārabhet $\|140\|$}

One should meditate upon the internal [wheel/cakra] as external, and the external likewise as internal. Considering [these] to be identical, one should then commence installation [of the mantra-deities] on the cakra.

The degree of correspondence is merely suggestive, and Abhinavagupta might have had in mind other BraYã passages. His language is actually somewhat closer to a verse from the Tantrasadbhāva, however, another early scripture of the Vidyāpitha division of Bhairavatantras. This is highly likely to postdate the BraYā and to reflect a degree of historical development vis-à-vis the latter. ${ }^{5}$ Tantrasadbhāva 6.218 may read as follows:

\section{adhyātmaṃ bāhyato dṛ̦țvā bāhyam adhyātmasamsthitam | yo jānāti sa siddhyeta tadbhāvabhāvabhāvitaḥ ${ }^{6}|| 218||$}

After viewing the inner (adhyātma) externally, one who [also] knows the outer to be located internally will attain success, purified by contemplation of their identity (?). ${ }^{7}$

It is conceivable that Abhinavagupta has conflated these two sources, though he may instead have had in mind a verse of the Brahmayamala not preserved in its oldest manuscript. More probably, he simply paraphrases his source with unusual freedom.

Regardless of which passage Abhinavagupta had in mind, a point of significant interest emerges from considering this question, namely that the Tantrāloka, Tantrasadbhāva, and Brahmayāmala all appear to mean something different by the distinction between adhyātma, "inner/directed towards the self," and ba ahya, "external." For the Tantrasadbhāva, the performative acts and paraphernalia of ritual have superior, inner (adhyātma) equivalents: the outer (bāhya) finds its true meaning in the inner processes of yoga. Thus, for instance, in the section of Tantrasadbhāva 6 quoted above in excerpt, the external rosary made

5 See the discussion in Hatley 2018, 100-104.

6 For the full passage with critical apparatus, see note 8 below.

7 Tantrasadbhāva 6.218d—tadbhāvabhāvabhāvitah (or tadbhava ${ }^{\circ}$ )—is unmetrical and problematic; I have understood tad as tayoh, referring to the pair of adhyātma and bāhya (inner and outer). 
of conch (śamkha) has as its inner form the subtle śaṃkhā or śaṃhinī channel (nāa $\bar{\imath}$ ) of the yogic anatomy, which extends into the crown of the head. ${ }^{8}$ The 'outer' thus finds true purpose in the 'inner' realities of yoga, which supersede the outer entirely. This principle applies to sacred geography as well, for the Tantrasadbhāva transposes into the yogic body a series of cremation grounds closely related to those of the $B r a Y \bar{a} .^{9}$ Access to these inner levels of meaning is a form of knowledge: the inner sacred geography is understood (jñätavyam ) by those who know the self (viditātmanām), while only "one who knows [the identity of inner and outer] attains success" (yo jānāti sa siddhyeta). Knowledge (jñ̄ana) thus transforms ritual into an inner process through which it

8 Tantrasadbhāva 6.217-22ob (based on the draft edition of Marc Dyczkowski, which reports the readings of three manuscripts, $\mathrm{k}, \mathrm{kh}$, and $\mathrm{g}$ ):

ete cāștāasáa proktā akșasūtrā bahisthitāh |

adhyātme ca gatās tv ete sāmpratạ̣ tān nibodha me $\| 217 \mid$

adhyātmam bāhyato dṛ̦țvā bāhyam adhyātmasaṃsthitam |

yo jānāti sa siddhyeta tadbhāvabhāvabhāvitah ||218||

ekaivādhyātmagaṃ sūtram prāg eva kathitam mayā |

śaṃkhāvartā tu yā nā dì śikhānte tu vyavasthitā ||219||

tena śaṃkhamayī proktā akṣasūtraṃ varānane |

${ }_{21} \mathbf{b}$ bahisthitāh] em.; vahisthitā k, kh, g $217 \mathrm{c}$ tv ete] $\mathrm{k}$, g; tvate kh 218a adhyātmam ] corr.; adhyātma mss. $\quad \mathbf{2 1 8 b ^ { \circ }}{ }^{\circ}$ samsthitam] em. (Dcyzkowski); saṃsthitā mss. $\quad 218 d$ tadbhāova ${ }^{\circ}$ ] k; tadbhava ${ }^{\circ}$ kh, g $219 \mathrm{~b}$ prāg eva] kh; prog eva k, g 219c śaṃhāvartā] kh; saṃkhyāvartāa k, g 219d śikhānte tu] k, g; śikhāntera kh 220a śaṃkhamayī] k, g; śaṃkhamayam kh 22ob akșasūtraṃ] em. (Dyczkowski); makșasūtram mss.

On śaṃkhāvartā as a nāḍ̄, see Amaraughaśāsana 6o, which describes it as "having the measure of a lotus fibre" (mrṇālasütraparimānāa ). The more commonly attested name is śamkhiṇi.

9 See especially Tantrasadbhāva 15.62-67:

prayāgā nābhisaṃsthā tu varuṇa hrtpradeśata[h] |

kolagiryām tu kaṇthastham bhìmanādam tu tāluke ||65||

bindusthāne jayantyāṃ tu nādākhye tu caritrakam |

ekāmrakam śaktimadhye jñātavyam viditātmanām $\|66\|$

guruvaktragatam proktam koțivarșam tathāștamam |

ete sthānā mayā proktā adhyātme pudgalāśrayāh ||67||

For those who know the Self, Prayāga should be understood as located in the [cakra of the] navel, Varuṇā [i.e. Vārānasī] in the heart region, Kolagiri in the throat, Bhīmanāda in the palate, Jayantī in the place of Bindu, Caritra in [the plexus] called Nāda, and Ekāmraka in [the plexus of] Śakti. The eighth, Koțivarșa, is likewise said to be in the Mouth of the Guru. These are the places I have declared to be present in the person internally (adhyātme).

This list of eight pițhas overlaps with the nine śmaśānas or pițhas of the BraYä's principal mandiala (as outlined in chapter 3; see Kiss 2015, 24); however, it corresponds more precisely to the eight delineated in BraYā 87 (see Hatley 2018, 134, table 1.16). Cf., also, Tantrasadbhāva 15.70: kulüttamoḍdiyānam ca eruḍ̄ pulivallabham | tāny eva tu samastāni [em.; saman tāni mss.] svadehe samsthitāni tu $\|$. 
ultimately achieves fruition - an orientation consonant with the Kaula turn towards interiority, which may presage aspects of Abhinavagupta's gnostic nondualism. Yet in contrast to the latter, for the Tantrasadbhāva, the inner is nonetheless conceived of in terms of 'doing' (kriy $\bar{a})$ rather than 'knowing' (jñāna). The inner and outer, respectively, represent higher and lower arenas of activity, for the mental processes of meditation are also forms of action $(k r i y \bar{a})$. Chapter 26 of the Tantrasadbhāva colourfully proclaims this principle:

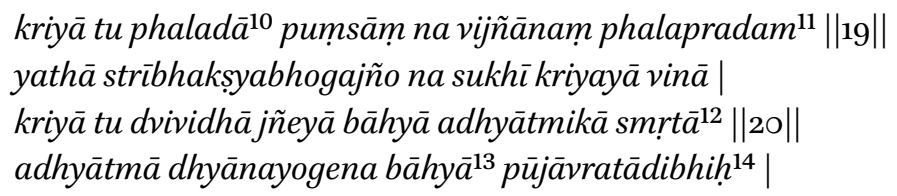

Doing $(k r i y \bar{a})$ is what gives people results; knowledge does not produce results, just as a man knowledgable in the sexual enjoyment of women is not happy without doing it $(k r i y \bar{a})$. But doing should be understood as twofold: it is held to be outer and inner. Inner action $(k r i y \bar{a})$ is through yogic meditation, while outer action is through worship, ascetic observances, etc. ...

Knowledge is here conceptualized neither in processual nor gnostic terms: jñāna and kriya represent a dichotomy along the lines of "theory" and "practice."

The BraYā likewise embraces the twofold division of kriya into inner and outer - adhyātma and bähya - which refer in its usage to subjective processes performed mentally and to the somatic performance of ritual, respectively. In contrast to the Tantrasadbhāva, the BraYä draws no overt hierarchy between the two. The inner does not represent a higher meaning or reality; the inner and outer rather represent complemetary arenas for the performance of ritual whose integration is essential. The inner and outer find their fullest integration in the performance of yāga or yajana, "pantheon worship," the paradigmatic mode of ritual whose limitless possibilities for inflection account for much of the BraYä's bulk. Yet the principle of their unity applies widely, extending to all

\footnotetext{
10 phaladā] em.; phaladāḥ mss.

11 Cf. Śrīkaṇțha's Ratnatrayaparīkșā, 129ab: kriyā hi phaladā puṃsām na jñānaṃ syāt phalapradam.

12 smrtā] em.; smrtāḥ mss.

13 bāhyā] em.; bāhya mss.

14 vratādibhih] $\mathrm{k}, \mathrm{kh}$; vratedibhiḥ g.
} 
of the various practices encompassed by the terms kriya and karman, including fire ritual (homa), rites of installation (pratișthā), initiation (dīkșa $)$, durational observances (vrata), rites using deity images (pratimākarman) or twodimensional diagrams (yantrakarman), and so forth..$^{15}$ This integration of inner and outer practice makes a rigid distinction between "ritual" and "meditation" artificial: in the context of the BraYā, ritual—krìy or or karman—encompasses both outer and inner forms of action. These are remarkably parallel in structure and process, and aim at the unification of subjectivity, body, ritual space, paraphernalia, and the hierarchy of ontic principles (tattva) which comprise the cosmos (adhvan). In this respect, despite its cultic affinity to later Kaula systems, the BraYä's harmonious integration of the inner and outer seems largely congruent with classical Śaivasiddhānta ritualism. Arguably, such integration of inner and outer processes is characteristic of tantric ritual, broadly conceived, as reflected in the ubiquitous dichotomy of antaryāga ("inner worship") and bahiryāga ("external worship"). What is most distinctive to the BraYā is its unique manner of their integration: the "method of the lotus garlands" (padmamālāvidhi).

\section{Method of the Lotus Garlands ( padmamālāvidhi)}

Patterning the processes of inner and outer ritual is the BraYä's pantheon of mantra-deities, whose core comprises the Four Goddesses ( $\operatorname{dev} \bar{\iota})$ or Guhyakās, Four Consorts (dūtīs) or Handmaidens (kinkkarī), and their lord, Kapālissabhairava. Secondary members of the pantheon are a sextet of Yoginīs and an octad of Mother-goddesses (mätr). These (see table 16.1) are the mantra-elements manipulated in all practice, both inner and outer, and their permutations are the principal ritual variables. Collectively, the deities comprise the Nine-Syllable Vidyā (navākșarā vidyā), mantra of the supreme goddess, Caṇ̣ā Kāpālinī, as first identified by Sanderson $(1988,672)$ in his pioneering remarks on the BraYā. In syllabic terms, the vidyā is [OṂ] HŪṂ CAṆ̣̣E KĀPĀLINI SVĀHĀ.

15 Cf. BraYā 90.101: anena vidhinā devi japahomādikarmasu [corr.; karmașu ms.] | bāhyādhyātmeva mantrajñah püjām [em.; püjyām ms.] kurvan prasidhyati ||101|| ("Through this procedure, $\mathrm{O}$ goddess, in mantra incantation, fire sacrifice, and other rites, the knower of mantras achieves siddhi, practicing both external and internal worship"). In 1o1c, bāhyādhyātmeva should be understood in the sense of bähyādhyātmām eva-nominative for accusative, metri causa. 
TABLE 16.1 Deities of the Nine-Syllable Vidyā

\section{Kapālīśabhairava (HŪṂ)}

\begin{tabular}{|c|c|}
\hline FOUR DEVĪS & FOUR DŪTĪS \\
\hline Raktā (CAM) & Karālā (LI) \\
\hline Karālī (ḌE) & Danturā (NI) \\
\hline Caṇụākṣī (KĀ) & Bhīmavaktrā (svĀ) \\
\hline Mahocchușmā (PĀ) & Mahābalā (HĀ) \\
\hline SIX YOGINĪS & EIGHT MĀTṚS \\
\hline Kroșțukī (OṂ HŪṂ CAṆḌE & Maheśvarī (AṂ) \\
\hline KĀPĀLINI NAMAب̣) & Brāhmī (E) \\
\hline Vijayā (ọ̣ ... svĀHĀ $)$ & Vaiṣnạavì $(\overline{\mathrm{A}})$ \\
\hline Gajakarṇā (ọ̣ ... HỤ̄̄) & Kaumārī (A) \\
\hline Mahāmukhī (ọ̣ ... VAUṢAṬ) & Vaivasvatī $(\overline{\mathrm{I}})$ \\
\hline Cakravegā (ọ̣ ... VAṢAṬ) & Indrāṇī (I) \\
\hline \multirow[t]{2}{*}{ Mahānāsā (OṂ ... PHAṬ) } & Caṇdikā (svā) \\
\hline & Paramā/Aghorī (HĀ) \\
\hline
\end{tabular}

Virtually all ritual begins with the instruction to enter into a state of meditative concentration, called nirācāra, and to take on a body of śakti, called the avadhütatanu. ${ }^{16}$ Śiva is the nirācārapada, "the state beyond regulated conduct," while the Goddess is avadhütä, "the stainless/unblemished one."17 The avadhüta-body, the body of śakti, is a body of mantra (mantravigraha) engendered by the placement of mantra-syllables in a series of bodily lotuses. The process of taking on the avadhüta-body culminates in assumption of one's inner identity as Kapālīśabhairava at the heart of a manḍala of goddesses, all of whom collectively comprise the Nine-Syllable Vidyā. Although framed as a

\footnotetext{
16 Note, for example, BraYā 3.187c-189b: ekākī vijane tasmim dakṣinābhimukhasthitah ||187\| muktakeśaś ca digvāsaḥ krtanyāso vidhānavit | avadhūtanur bhūtvā nirācāras tu sādhakaḥ ||188|| prathamam pūjayed devam karṇnikāyām paraṃ śivam |. Cf., e.g., 8.3-4b: tato hy ekamanā bhūtvā avadhūtatanuḥ sthitạ̣ | nirācāreṇa bhāvena yadā paśyati sarvvatah ||3\| tadā karoti karmānni vicitrāṇi mahìtale |; cf. also 47.17c-18b: tatạ ekāgracittas tu avadhūtatanusthitah ||17|| nirācārena bhāvena smared vidyām suyantritah |.

BraYā 2.2cd: avadhūtā tu sā śakti nirācārapadah śivaḥ (= 62.98ab).
} 
preliminary to ritual action, this process of mantra-installation (nyāsa) is in fact the very template of ritual, both inner and outer; it has both elaborate and abbreviated forms, with numerous inflections. I here summarize one of several long descriptions of this process, the padmamālāvidhi ("method/procedure of the lotus garlands") of BraYā, chapter 4 (vv. 497 ff.):

First one visualizes the avadhütam (i.e. the avadhütā śakti), whose function in this application is analagous to the a adhäraśakti ("basal power") of most Śaiva systems. ${ }^{18}$ This begins preparation of the practitioner's body as locus for installation of the deities, from the crest (śikhā) of the head to the feet. A series of nine lotuses is visualized situated at points in the body called granthis (knots or joints). These are located at the crown of the head (śikhā), the forehead (laläta), throat (kaṇța), navel (nābhi), knees (jānu), mouth (vaktra), heart (hṛd), genitals (guhya), and feet (pāda), following the order of their sequence in nyāsa. The eight-petalled lotuses situated therein are loci for installation of the principal nine deities: Kapāliśabhairava, who is installed in the crown lotus, and two sets of four goddesses, the Devīs and the Dūtīs. In each lotus one prepares a mantric seat for the deity, whose complete mantra-forms are then installed, inclusive of their ancillary mantras (anga). ${ }^{19}$ Each of the eight goddesses is installed in a lotus along with the mantra-body of Kapāliśabhairava, who is thus coupled with each goddess. ${ }^{20}$ This series of nine forms the Brahmayāmala's principal padmamālā, the garland of Devīs and Dūtīs, which is illustrated in figure 16.1. While one might associate bodily lotuses with the body seated in yogic meditation, here a standing position with the legs together is implied, for a single lotus presides over the two knees and likewise feet.

Next is installed a second series of seven lotuses, the garland of Yoginīs (figure 16.2b). ${ }^{21}$ In contrast to the first lotus garland, these do not lie in a vertical axis. Three form a kind of girdle: one lotus is placed in the center

18 Concerning the ādhāraśakti, see the article on this term in Tāntrikābhidhānakośa, vol. I.

19 BraYā 4.497c-5orb: adhunā [em.; adhuna ms.] sampravakșyāmi padmamālāvidhikramam [em.; '̊idhih kramam ms.] ||497|| śikhādipādayor antạ̣ [em.; antā ms.] avadhūtaṃ vicintayet | navagranthivibhāgena tayā [?] proktā punah kramāt ||498|| navapadmāni saṃcintya aștapatrāṇi sādhakah | yuktāni keśaraiś caiva caturvvinsatibhịh kramāt ||499|| karṇnikāyām yutānīha cintanīyāni mantriṇā | śikhāpadmam [em.; ${ }^{\circ}$ padma ms.] samārabhya āsanāni prakalpayet ||500|| vakșyamānena nyāyena padme padme na saṃśayah |.

$20 \quad$ BraYā 4.516-517b: vāmapārśve tatas tasyā kapāliśasya vinyaset | büjamātram mahāprājña vaktraneträngavarjitam ||516|| tasyopari nyased devi bhairavaṃ mantravigraham |.

21 BraYā 4.523c-529. 
of the waist, on the back (kațiprșthe), while the other two lie on either side of the waist. The remaining four lotuses are situated on the sides of the knees and feet. Installed upon these lotuses are goddesses known as the Six Yoginīs, led by a male deity, Ādivīra ("Primordial Hero"), positioned in the lotus on the back of the waist (see figure 16.2b).

A third series of lotuses serves as the locus for installation of the Eight Mother-goddesses (așta mätarah), accompanied by the male deity Mătrivira (figure 16.2a). ${ }^{22}$ In this case as well the lotuses do not form a vertical axis, lying at various positions on the head and torso: the points between the eyebrows (bhrümadhya) and between the eyes, the tip of the nose, and each ear. Next are a point between the throat and heart, another between the heart and navel, and an unspecified place on the back or spine ${ }^{23}$ locus of the goddess Carcikā or Cāmunḍā. The eighth mātr, the supreme śakti, Paramā, also called Aghorī or Yogeśī, pervades the entire body, lacking a lotus base and being devoid of ancillary mantras. ${ }^{24}$

In figure 16.2, the second and third lotus garlands are shown together, thus illustrating the empowerment of the upper and lower bodies by mantra.

What renders the lotuses into garlands ( $p a d m a m a \bar{a} / \bar{a})$ is the thread which binds them. The BraYā first introduces this idea in presenting the second garland (that of the Yoginis), describing the lotuses as "bound together by the cord of śakti, like gems [strung] by a cord" (śaktitantunibaddhāni sūtreṇa mañayo yathā, $4.526 \mathrm{~cd})$. The terms utilized are śaktitantu and śaktisütra, meaning, respectively, a thread or a cord of śakti. This divine power binding the lotuses together is consubstantial with the supreme Goddess herself, the Nine-Syllable Vidyā whose being encompasses the deities of the manḍala.

A concept seemingly unique to the BraYā, the śaktitantu or śaktisūtra receives minimal explication. References to it occur almost entirely in the context of the "method of the lotus garlands" (padmamālāvidhi). In what manner the cord connects the lotuses of the three garlands is somewhat ambiguous. For the first garland, whose lotuses form a vertical series, the śaktitantu must

\footnotetext{
$22 \quad$ BraYā $4.530-538$.

23 BraYā 4.532cd: așțaman tu tathā prșțhe kalpayen mantravit kramāt.

24 BraYā 4.538: sarvvānge paramā śakti vaktranetrāngavarjitā| padmāsananvihīnā tu vinyasen mantravit kramāt $\|$.
} 


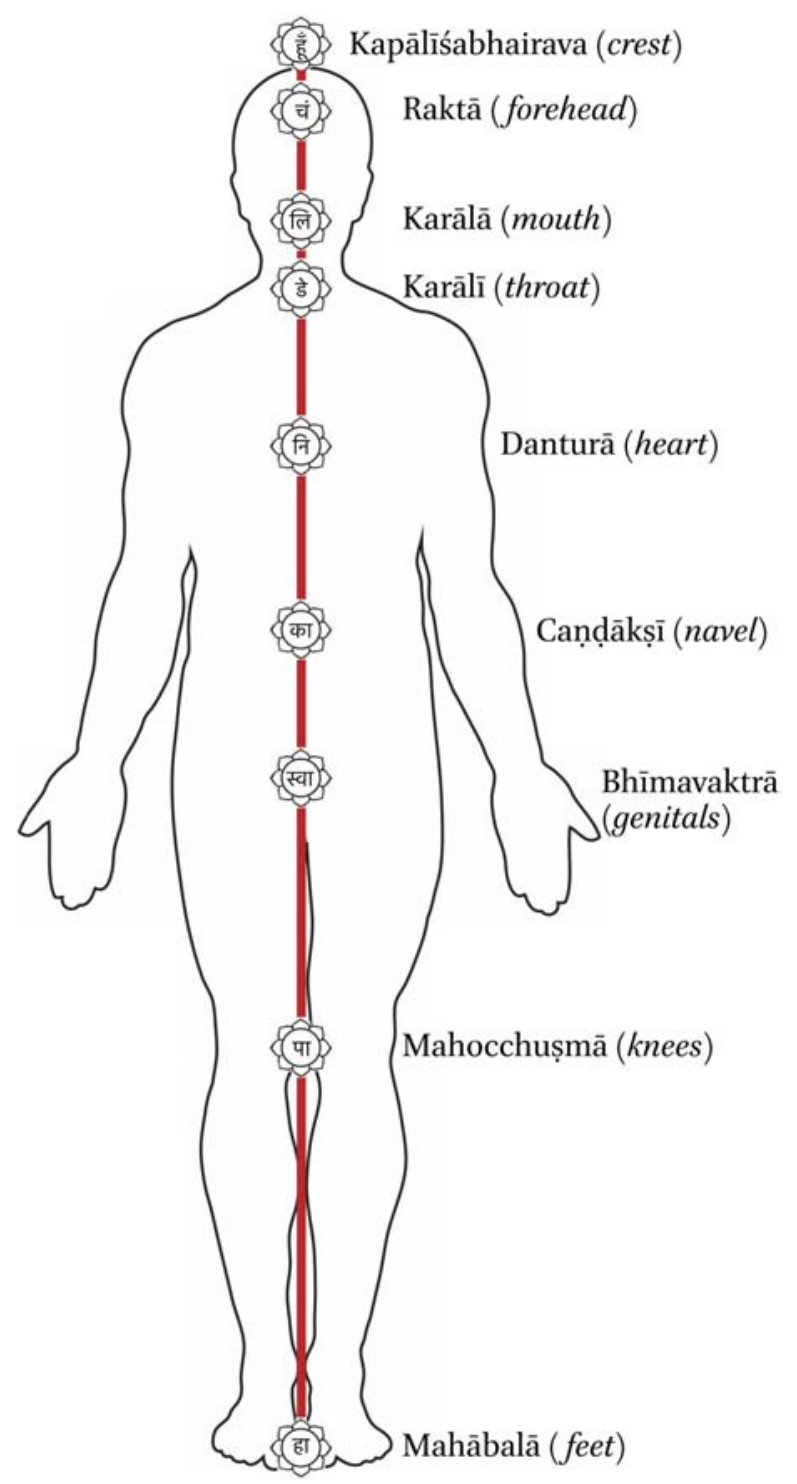

FIGURE 16.1 Garland of the Devīs and Dūtīs (padmamālā I) 
(a) Garland of the Mātṛs (padmamālā III)

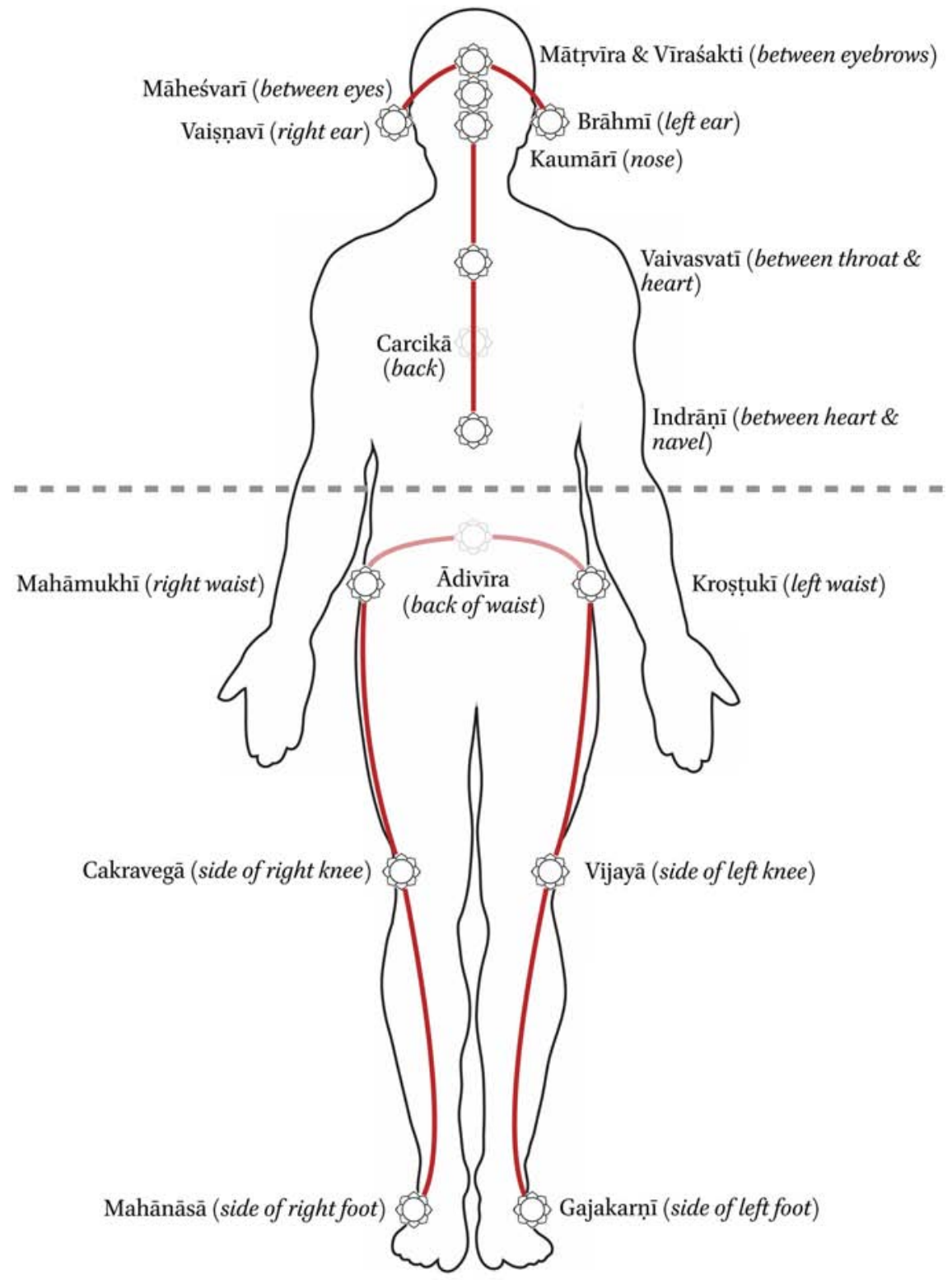

(b) Garland of the Yoginīs (padmamālā II)

FIGURE 16.2 Garlands of the Mātṛs and Yoginīs (padmamālās II-III) 


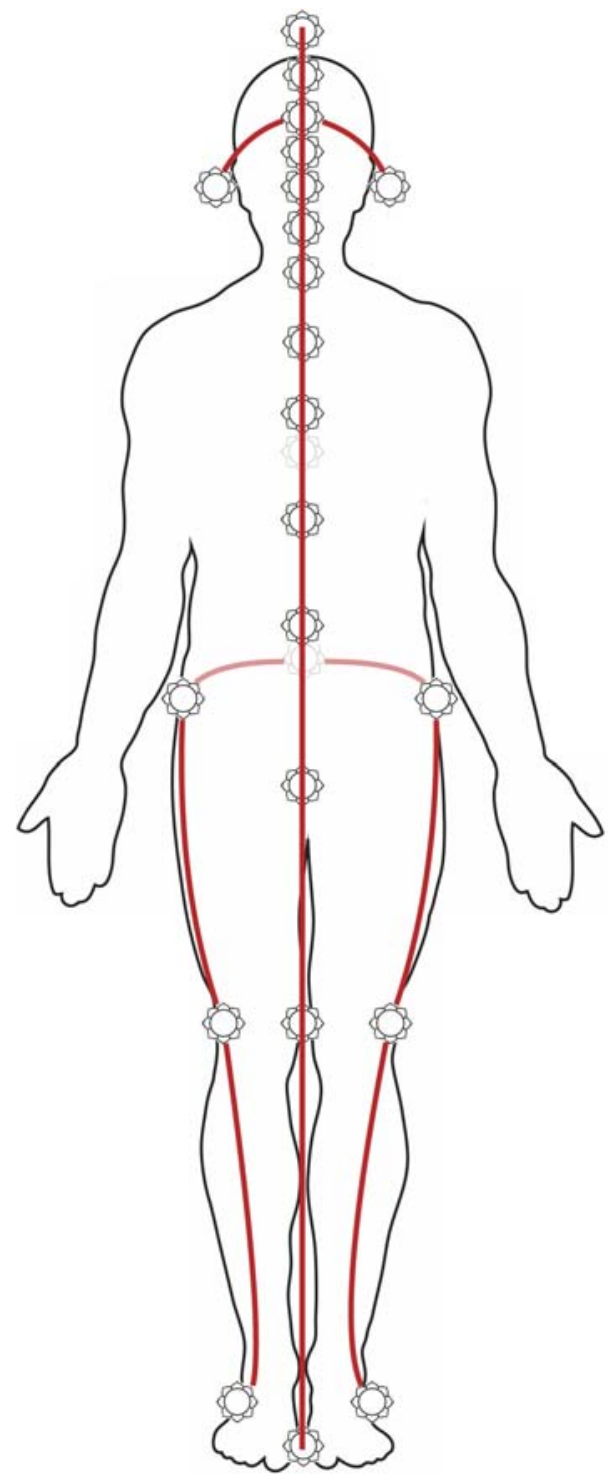

FIGURE 16.3 The pure body of power (avadhütatanu) 
string them together vertically from crest to feet (figure 16.1). In the case of the third padmamālā, the śaktisūtra likely begins from the lotus between the eyebrows (bhrumadhya), the uppermost of this series and locus of the male deity Mātrvirira, lord of the Mother-goddesses (mātr ). The cord pierces (bhid-) and thus strings together eight lotuses (figure 16.2a). ${ }^{25}$ Unlike those of the first garland, these do not form a vertical axis in the body, and it is unclear precisely how and in what sequence the śaktitantu links them together: does the cord form a garland-like closed circuit, or connect the lotuses like a strand? This śaktitantu extends through the body in three dimensions, for the seventh lotus is located on the back, forming the locus of Carcikā, i.e. Cāmuṇ̂ā ${ }^{26}$ In the case of the second padmamālā, that of the yoginis, the manner in which the śaktitantu connects the lotuses seems less ambiguous (figure $16.2 \mathrm{~b}$ ). The garland is threaded from a lotus on the back of the waist, ${ }^{27}$ extending outwards to lotuses on the sides of the waist, then downwards to lotuses on the sides of the knees and feet. Although this is not explicitly stated, the cord might connect the footlotuses together in a garland-like manner, so forming a closed circuit.

The principal series of nine lotuses spans the body's axis from crest (śikhā) to feet, linked by the śaktitantu and thus forming a vertical strand (figure 16.1). This vertical sequence of bodily lotuses connected by a cord of śakti has obvious similarities with models of the yogic body in which sușumnā nādì, the central channel, links together an ascending series of cakras or lotuses. This ubiquitous paradigm is exemplified by the system of seven cakras common to Śrīvidyā and Hațhayoga, identified by Sanderson $(1988,687-688)$ as being first attested in the Kubjikämata. Like the śaktitantu, the sușumnā is closely identified with śakti, especially in the form of the bodily kundalinī. The sușumna of yoga and the BraYä's śaktitantu both unite a vertical series of lotuses situated at particular "knots" (granthis) in the body, including such standard locations as the crest, forehead, throat, heart, navel, and genital region. While the sușumna came to be envisioned as a vertical channel extending upwards from the heart, navel region, or base of the torso, ${ }^{28}$ there is an old precedent for the idea that it extends, like the śaktitantu, to the feet: the Matangapārameśvara, a comparatively early Siddhāntatantra, envisions the sușumnā running from

25 BraYā 4.53o: bhruvo madhye tataḥ padmaṃ śaktiśütreṇa pūrvvavat | bheditậ -m-āditậ (?) krtvā anyāny api tathaiva hi $\| 53$ o $\|$.

26 BraYā 4.536cd: prsțtipadme tu devesi carccikām vinyased budhah.

27 BraYā 4.527c-529: virran tu trikapadme tu kațiprșțhe tato nyaset $\|_{527}||$ vaktranetrānigasamyuktạ̣ vīraśaktyā samanvitam | büjamātraniviștāyạ̄̄ vāmapārśve tathaiva ca \|528\| vāmakatyādim ārabhya yoginyo vinyaset tathā | vaktranetrāngasamyuktāh padme padme na saṃśayah $\left\|5^{29}\right\|$.

28 See Tāntrikābhidhānakośa, vol. III, entries for pingalā, nāḍ̄, nābhi, and nābhikanda. 
the tips of the big toes to the crown of the head via the navel and heart.. ${ }^{29}$ This archaic model of a central channel extending to the feet, linking together various granthis, may underlie the BraYä's conception of the śaktitantu.

It should perhaps be emphasized that the BraYä's series of lotuses do not in any simple sense represent "structures" of a subtle or "yogic" anatomy. The lotus-seats ( $\bar{a} s a n a)$ of the mantra-deities are created through meditative visualization: one actively engenders a divine body of mantra rather than reifying a subtle reality already latent in the body. More precisely, through the padmamälāvidhi, one imaginatively superimposes the mantric body (mantravigraha) of Bhairava upon one's own corpus and psyche. That the deity-lotuses do not represent fixed structures of a subtle body is illustrated by variations in their sequence: chapter 21 provides an alternative order of the principal nine deities, placing Bhairava in the heart, ${ }^{30}$ while an inflection of the padmamālāvidhi in chapter 45 inverts their typical sequence, placing Bhairava in the lotus of the feet. ${ }^{31}$ An alternative version of the second garland has the lotuses of the Six Yoginīs encircle the waist like a girdle. ${ }^{32}$

Nonetheless, while the BraYā does not treat the lotus garlands as fixtures of a subtle body, it does posit the existence of such structures: the body's channels

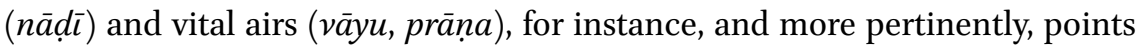
known as granthis ("knots" or "joints"). A particular series of nine granthis forms the locus for installing the nine lotuses of the primary padmamāla granthis were considered to be anatomical realities is suggested by their treatment as points in the body rather than as objects to be placed/installed (nyas-) in the body or engendered through meditation (kalp-, cint-, etc.). ${ }^{33}$ Integral to the idea of the padmamāla is this correlation between a vertical sequence of

29 Matañgapārameśvara, vidyāpāda 20.21c-22b: pādāngusțhāgrato vyaktā nābhito hṛdayam gatā || 21|| suṣumnā nāma sā jñeyā brahmarandhrābjanirgatā |.

30 BraYā 21.125ab: hṛdaye bhairavo nyasya vaktranetrāngasamyutam (understanding bhairavo as accusative in sense).

31 In BraYā 45.390-397, the sequence of installation (nyāsa) for inner worship is from feet (Bhairava) to head (Paramā Śakti). See the notes of Kiss (2015, 281-282).

32 BraYā 21.128-129:nābhyām vaivīra vinyasya tato vāmādi-m-āśrtāhh| mekhalākrtisamsthānāa katyām vai yogin̄̄ nyaset || 128|| dakṣiṇāpārśvakam yāvad vāran tu varavarnini | vaktranetrāngasamyuktā kartaryā nātra saṃśayah $\|129\|$.

33 The granthis are referred to solely by their locations in the body. Take for example BraYā $4.5^{64} \mathrm{c}-565$, which specifies the "knot of the throat" (kant thagranthi) as locus for the lotus of goddess Karālī: anenaiva vidhānena karālị̄m [em.; karālī ms.] vinyaset punaḥ \| kaṇthagranthigate [em.; ${ }^{\circ}$ sate ms.] padme nātra kārya vicāraṇāt | nābhipadme [em.; ${ }^{\circ}$ padmes

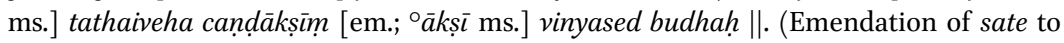
gate is trivial, given the frequent confusion of śa and ga in the old manuscript, and the interchangability of śa and $s a$.) 
lotuses and the body's nine knots, which are repeatedly described as dividing the garland. ${ }^{34}$ In the case of the two secondary padmamālās, the lotuses' positions in the body do not on the whole correlate with granthis. This supports the idea that the primary padmamāla is rooted in a model of the yogic body in which nine granthis are united by a central channel (nādi ), which the BraYā reconceives of as the śaktitantu. This cord of śakti, unique to the BraYā, appears to combine what in later traditions would be differentiated as the sușumnānā $\bar{d} \bar{\imath}$ and the bodily (as opposed to cosmogonic) kundalini $\overline{.}^{35}$

Although archaic tantric conceptions of the yogic body may have inspired the $B r a Y a a^{\prime}$ s lotus garlands and cord of power, the concept primarily describes the practitioner's assumption of a divine body of mantra. This avadhütatanu, "body of pure śakti," is formed by lotuses of the three garlands and united by the śaktitantu, shown as whole in figure 16.3. This embodies the entire pantheon of deities as well as the hierarchy of ontic levels (tattvakrama), from the earth element to paramaśiva. ${ }^{36}$ The avadhütatanu taken on by the sädhaka mirrors, in part, the mantra-body of the deity as Sadāśiva; his divine form is composed of a garland of nine lotuses pierced by the cord of power, further augmented by a triad of cosmological powers-vāmā, raudrī, and jeșthā..$^{37}$ To assume the

34 Note for instance BraYā 21.123c-124b: śaktitantunibaddhān tu padmamālāṃ [em.; mālā ms.] vicintayet ||123|| navagranthivibhāgena tato nyāsam prakalpayet | ("One should visualize the garland of lotuses as bound by the cord of śakti, then one should perform mantra-installation, according to the division of the nine knots [where are positioned the lotuses]").

35 Key to this issue is the question of whether and by what other names the BraYā conceives of a central channel (nāậ). While the BraYã does attest the common nādi triad of $i d \bar{a}$, pingalā, and sușumnā, the expression sușumna (which in most sources refers to the central channel) occurs only once (18.80) in the earlier stratum of the BraYä-its first fifty chapters. Its meaning in later chapters, where it does occur several times, is ambiguous. It may not (always) be the middle channel: it is never specifically designated as such, and BraYā 85.138cd seemingly refers to an unmamed middle channel between iḍa and sușumnā (iḍa suṣumnayor madhye muktimārggānusāriṇi ). Concerning the early history of sușumnā, see the preliminary remarks of Goodall et al. (2015, 33-34).

36 Note e.g. BraYā 45.104ab: śaktitantu tato dhyātvā śivādyavanigocare. Similar expressions abound in the BraYā.

37 BraYā 32.42-46:

evaṃsvarūpasampannam cintayìta sadāśivam evamsthito mahādevi ādidevah sadāśivah $\|42\|$ svayaṃsthito sthitim kuryā trailokye tu na saṃśayaḥ | saṃhāraṃ tu sadā kuryād icchayā caiva saṃharet ||43\| dahyātmanaḥ punas sarvạ̣ trailokyạ̣ sacarācaram | srjate tu yadātmānam trailokyam sṛjate sadā $\mid 44 \|$ vāmayā srjate sarvam raudryā caiva tu saṃharet | jeșthayā ca sthitim kuryā tritattvatanusamsthitaḥ ||45|| 
avadhütatantu is, more specifically, to take on the mantra-body (mantravigraha) of Kapālissabhairava, the deities of whose largely female maṇala pervade the lotus garlands. Strung together by the cord of sakti, the lotuses of all the goddesses are also simultaneously loci of Bhairava, whose seed-syllable HŪM appears in each, paired with the presiding goddess. ${ }^{38}$ Thus it is that the BraYä's opening benediction invokes the bhairavatattva as sporting in the form of the lingam in the lotuses of his consorts. ${ }^{39}$

While the sädhaka seeks apotheosis as Bhairava, the divine body he takes on, the avadhütatanu, in fact consists of a feminine power which ultimately transcends the male deity. The "unblemished" or "pure" (avadhütā) śakti is present not only as the cord which unites the lotus garlands: in mantric terms, she also pervades the garlands as HĀṂ, the final syllable of the Nine-Syllable Vidyā (with the addition of anusvāra). In this form she is known as Paramā or Yogeśī, the eighth and highest Mother-goddess from whom the others emerge, ${ }^{40}$ and as Aghorī or Bhairavī, consort of Bhairava. Her simultaneous pervasion of the body and syllabic presence in each lotus are intimated in BraYã 4.595-596b:

sarvvāñge paramā śaktir ${ }^{41}$ vaktranetrāngavarjitā $\bar{a}^{42}$

padmāsanavihīnà tu vinyaset sādhakottamah $\|595\|$

padmamālaị samāyuktā padme padme vikalpayet |

The best of sädhakas should install the supreme sakti [HĀṂ] on the entire body, without face, eye, or limb mantras, devoid of a lotus seat; one should [also] envision her in each lotus, conjoining/possessing the lotus garlands.

navāṃbhojakṛtām māàām śaktisūtreṇa bheditām |

navagranthivibhāgena bibhrāṇo parameșvaraḥ $\|46\|$

43d icchayā] em.; icchayo ms. $\quad$ 44a sarvam] em.; savam ms. $\quad 44 \mathrm{c}$ srjate] corr.; śrjate ms. $\quad$ 45a srjate] corr.; śrjate ms. $\quad$ 45c jeșțayā ca sthitiṃ] em.; jeștayāvasthitaṃ ms. 46d bibhrāno] em.; bibhranau ms.

38 E.g. BraYā 4.515, concerning the lotus in the forehead of goddess Raktā: vāmapārśve tatas tasyāḥ kapālīsasya vinyaset | büjamātram mahāprājña vaktranetrāñgavarjjitam $\|$.

39 BraYã 1.1b: dūtīnām padmașaṇde 'samasukhavilasal lingarūpaṃ bibharti; see the discussion in Hatley 2018, 383-385.

$40 \quad$ BraYā 2.17-18: hākāreṇa parā śaktir etā yasyā vinirgatāh | mātaras te mayā proktā yāge ucchușmapūjite ||17|| yā sā eva mayā proktā mātṛ̣nāã caiva pūraṇi | tasyedam kathitam sarvaṃ yam jūātvā nāvasīdati $\|18\|$.

41 śaktir] em.; śakti ms.

42 varjitā] corr.; varjitāḥ ms. 
As holds true for the deity mandala in all its forms, the supreme goddess has a transcendent, subtle presence, lacking a singular locus. ${ }^{43}$ Thus while Kapāliśabhairava reigns from the uppermost lotus, the formless, all-encompassing reality to which the sädhaka aspires is "a feminine power which transcends the male-female dichotomy which patterns the lower revelations" (Sanderson 1988, $672)$.

\section{3}

\section{Yoga and the Integration of Inner and Outer Ritual}

The "method of the lotus garlands" (padmamālāvidhi) has more and less elaborate forms and numerous inflections. At its simplest, one installs the seedsyllables of the principal deities in nine lotuses. ${ }^{44}$ The procedure of the lotus garlands applies not only to the body, but to ritual involving external supports as well. Thus for the worship system ( $y \bar{a} g a)$ taught in chapter 12, one begins by laying out nine lotuses in a square mandala on a substrate, then visualizing the śaktitantu and installing the mantra-deities. ${ }^{45}$ After envisioning an elaborate mantric throne for installation of Bhairava in the central lotus, one engages in the somatic performance of worship. Subsequently, the procedure is replicated in full detail inwardly "by the path of yoga" (yogamārgena), seated in the lotus posture. ${ }^{46}$ 'Outer' ritual thus begins with meditative visualization and is followed by the rite's recapitulation internally.

While the padmamālàvidhi represents a basic template for ritual and the empowerment of the body, ritual may be patterned by divergent pantheons, especially the practitioner's personal pantheon (svayāga), a configuration of the mantra-deities established through initiation. These personalized inflections of the root pantheon (the mülayāga) are nine in number, based on the predominance of each of the nine major deities in turn. ${ }^{47}$ In the obligatory daily worship (nityakarman) and much other ritual, inner worship (hrdyagga) of this specific pantheon forms the standard preliminary to bahirnyāsa, the act of

43 See the discussion of Kiss $(2015,20-22)$, a section fittingly titled "Where is Caṇ̣ā Kāpālinī?"

44 This minimal (svalpa) form of nyāsa is described in BraYã 18.75-79.

45 BraYā 12.1-3: athātah sampravakșyāmi āsanaṃ pūrvvam eva hi | yāgaṃ caiva mahādevi sādhakānām hitāya vai $\|1\|$ pūrvvokte maṇdale caiva gandhamaṇdalake pi vā | pușpamaṇdalake vāpi śaktitantu vicintayet ||2|| tasyādho praṇavam dadyā kālāgnin tatra vinyaset | kșïrodam tan tu vinyasya avadhūtam tato nyaset || 3|| .

$46 \quad B r a Y a \overline{1} 12.29 \mathrm{ff}$.

47 Concerning the nine pantheons (navayāgāh), see the brief remarks in Kiss 2015, 16-18, and the article navayāga in Tāntrikābhidhānakośa, vol. III. 
installing the mantra-syllables upon the body or another substratum, whether the fire pit, ritual vessel, or icon. ${ }^{48}$ Applications of mantra-deity pantheons not based upon the Nine-Syllable Vidyā also follow this alternating pattern of inner and outer ritual. While worship ( yāga, yajana) provides the essential paradigm for the BraYä's integration of inner and outer ritual, the principle and practice of their integration applies more widely. This is abundantly evident in the domain of "magic," including all manner of rites involving alphabetical wheels (cakra), images of the deities ( pratima $\bar{a}$ ), and two-dimensional figures (yantra). These processes may entail, for example, the fusion of the channels of one's own body with the spokes drawn in the lotus of a cakra-the term nädi refers to both - which may then be fused with the channels of the targeted victim (sādhya). ${ }^{49}$

Given the integral unity of outer and inner ritual, of somatic acts and subjective processes, the question arises as to whether and in what manner 'yoga' represents, for the $B r a Y \bar{a}$, a domain of practice meaningfully distinct from 'ritual' (kriy $\bar{a}$ or karman). The evidence is ambiguous, at least for what seems likely to be the core, early stratum of the text (chapters $1-50$, more or less). ${ }^{50}$ Occurrences of the term yoga in the sense of meditational practice-often in the phrase yogamärgena, "via the path of/by way of meditation"-generally seem synonymous with inner ritual (adhyātmakriyā). Chapter 12, for instance, describes the procedure of the inner padmamā $l \bar{a}$ as "installation of the sakti" (śaktinyāsa) through "visualizing by way of yoga" (yogamārgena saṃciṃtya, $\left.{ }_{12.35} \mathrm{~cd}\right) .{ }^{51}$ On the whole, meditational disciplines are so well integrated into

48 E.g. BraYā 4.366c-367b: yāgasthānaṃ tato gatya hṛdyāgan tu prakalpayet ||366|| svayāgotthena mārgena bahi nyāsam tathaiva ca $\mid$. A detailed description of inner worship (hrd$y \bar{a} g a$ ) of one's own pantheon (svayāga) appears in BraYā 38.24c-31, in this case as a preliminary to fire ritual (agnikārya).

49 To give an example, I quote from my remarks on parakāyapraveśa ("entry into the body of another") in Tāntrikābhidhānakośa, vol. III: "PBY(H) [Picumata-Brahmayāmala] 14.254263ab describes a practice in which one should fuse (yojayet) the nāầis of the yogic body with those of a cakra of the kulavidyā-mantra of this system, inscribed on cloth, metal or wood $(\mathrm{PBY}(\mathrm{H})$ 14.240). In this case the purpose is the extraction of 'nectars': 'The sādhaka, thus exiting the body through the tip of the nose, should enter the body of another and perform the extraction of nectars, after fusing [his with the victim's] nädīs; about this, there is no need for deliberation' (evam dehā $[d]$ vinișkramya nāsikāgreña sādhakaḥ || paradeham vi[ś] et mantrī amrrtākrșțiñ ca kārayet | nāḍ̄saṃdhānakam kṛtvā nātra kārya vicāraṇāt, $\mathrm{PBY}(\mathrm{H})$ 14.259cd-26o)."

$5^{\circ} \quad$ See Hatley 2018, 64-71, concerning the BraYä's likely stratification.

$51 \quad$ BraYā 12.35c-4ob: yogamārggeṇa saṃcimtya śaktinyāsan tu kārayet || 35|| padmāsanopaviștas tu cintayitvā tu sādhakaḥ | avadhütạ̣ nyasen mantrī pādayor ubhayor api $\|_{36} 6$ pañcātmikā mahādevi guhye caturggunan tathā | hṛdayam trguṇaṃ nyasya lalāte dvigu- 
the $B r a Y a{ }^{\prime}$ 's ritual systems that to treat these as a distinct domain of practicewhether or not designated yoga - seems artificial. However, three brief chapters of the core text do focus on meditational practices which, exceptionally, seem virtually independent from somatic acts and external supports. ${ }^{52}$ Moreover, a passage in chapter 25 specifies that a sādhaka who aspires for liberation (the mumukșu), rather than supernatural experiences and powers (bhoga), should devote himself to a simplified pantheon worship ( $y \bar{a} g a)$, giving up all other rituals (karman) and "abiding by the path of yoga." While not abandoned, outer ritual here assumes a simplified form, the emphasis shifting decidedly toward inner practice. ${ }^{53}$ Thus the degree to which meditational disciplines feature primarily as integral elements of ritual may simply reflect the BraYä's emphasis on supernatural attainment (siddhi): the path of yoga, ultimately, is for seekers of liberation.

The Brahmayāmala likely has two or more distinct textual strata, ${ }^{54}$ and yoga proves to be an area in which stark contrasts emerge between these: later chapters of the text introduce yogic practices and emphases seemingly unanticipated in the core fifty-odd chapters. These include systems of meditation focused on a series of inner voids and resonances, ${ }^{55}$ a yoga system based on internalization of visionary encounters with the goddesses (yoginimelaka), ${ }^{56}$ yogic practices for cheating death (a system which, in contrast

ṇaṃ nyaset|| 37|| ekātmikā tathā caiva śikhāyām sādhakottamah | sakrt sakrt tathā caiva vaktrasthāneșu vinyaset ||38|| netrasthāneșu vai dadyād añgasthāneșu caiva hi | śaktitantu tato dhyātvā nmastakāt pādayo ntikā ||39|| bahirbhūtam śarīrastham padmamālān tu cintayet $\mid$.

These are chapters 36 (nādīisañcārapațala), 41 (bindupațala), and 44 (krị̄ākarmapațala). The latter, for instance, describes meditation upon the self in the lotus of the heart; merging with bindu, one gains the ability to traverse the universe in various forms. BraYā 44.23, 8: hṛddeśe kamalam dhyātvā vyomapañkajasamyutam | bindumadhye nyase 'tmānam [em.; nyasen mānam ms.] viśvadeham ayam śubham $\|2\|$ śaktibhị kiraṇopetạn tārāștakavibhūṣitam | tạ̣ dhyāyet paramam rūpam bindulīnam śivātmakam || $3 \|$... antarīkṣe tathā bhūmau pātāleșu ca dehișu | anya-m-anyeșu rūpeșu vicaren nātra saṃśayah ||8\||. For another example of the separation of meditation and ritual, BraYã 24.16c-17b speaks of meditative absorption (samädhi) as an activity one may engage in during interludes between the daily rites: japayukto kșapen mantrīprāta [r]madhyāhnikottaram $\|16\|$ śāstrasañgena vā saṃstho atha vā samädhișu sthitah [em.; sthitau ms.] |.

BraYā 25.341c-342: kevalasya mahādevi śivasya paramātmanah || 341|| bhairavākhyasya samprokto yāgo 'yam muktilakșaṇam | etad yāgatrayam proktam mumukṣo sādhakasya tu | nānyah karmanivrttasya yogamārgasthitasya tu ||342||. (Perhaps read anyakarmanivrttasya, "desisting from other rituals"?)

54 As argued in Hatley 2018, 64-71.

55 Chapters 92 and 99, respectively.

56 Chapter 100. 
to the core chapters, attests the bodily kundalinī), ${ }^{57}$ and a kind of "yoga of absorption" (layayoga) based on the granthis of the principal padmamā $\overline{l a} .{ }^{58}$ While not embeded within critiques of outer ritual, these diverse yogas of the text's later stratum tend to eschew external supports and somatic, performative acts. Far from being disciplines limited to the liberation seeker, these yogas offer the possibility of accomplishing the sādhaka's aims through inner acts alone, potentially superceding outer ritual. This is particularly evident in chapter 100, which teaches a "rite for mastery of the clans of goddesses through yoga" (yogena kulasädhanam). Attainment of direct, power-bestowing encounters (melaka) with the goddesses is one of the BraYä's dominant ritual aims, as illustrated by the "rite for the mastery of vetālas" (vetälasādhana, ch. 15), "rite of the great churning" (mahāmanthāna, ch. 46), "pavilion of power" (siddhimandapikā, ch. 47), and "worship in the pit [of power]" ([siddhi]garttāyāga, ch. 48). These virtuoso and macabre performances may culminate with the goddesses manifesting bodily before the sādhaka and granting boons. Belying this pattern, the yoga of chapter 100 offers the possibility of accomplishing mastery over the clans of goddesses through a process of inner realization alone. 59 Similarly, the yoga of BraYā 99 (called vijñānapañcaka, "the five knowledges") promises the ability to enter the bodies of others without recourse to external supports (cakra or yantra), through manipulation of a series of inner resonances $(r \bar{a} v a) .{ }^{60}$ Incorporation of such meditational disciplines into the text's latter strata marks a trend towards increasing differentiation between meditation and 'ritual' — between yoga and kriy $\bar{a}$ - and the subversion of outer forms of ritual. The possibility of attaining all ritual aims through yoga alone brings the vulgate BraYã closer to the Tantrasadbhāva's hierarchical dichotomy of the inner and outer, whereby the externalities of ritual are subsumed by inner realities. It is thus possible in this literature to trace early steps in the direction of Abhinavagupta's gnostic nondualism, which further overlays the dichotomy of jñāna and kriya upon that of inner and outer ritual.

\footnotetext{
57 Chapter 104.

58 Chapter 53 (cf. 99.19-35).

59 BraYā1oo.2-3b, 25-26: kulānām sādhanam nātha kathitan tu purā yathā | tat tathā viditam sarvam kulasiddhipradāyakam ||2|| sāmpratam sarahasyan tu yogena kulasādhanam | ... mātryoginikāyāni śākinīnān kulāni tu | sidhyanti sādhakendrasya yogenānena suvrate ||25|| yena [conj.; - na ms.] sarvagato bhütvā yoginīsiddhim āpnuyāt | kathayanti ca sadbhāvam kulajam jñānam uttamam $\|26\|$.

6o BraYā 99.3ocd: kṛtābhyāsas tu vai mantrī dehād deham vrajet kṣaṇāt \|.
} 


\title{
Acknowledgements
}

I would like to thank Alberta Ferrario, Dominic Goodall, Csaba Kiss, James Mallinson, and Alexis Sanderson for their stimulating comments on this essay. I would also like to thank Tadeusz Majewski for producing the line drawings which I have used for figures 16.1-3.

\section{Abbreviations}

\author{
BraYā Brahmayāmala \\ conj. conjecture \\ corr. correction \\ em. emendation \\ ms(s). manuscript(s)
}

\section{References}

\section{Primary Sources}

Amaraughaśāsana. Mukunda Ram Shastri, ed. The Amaraugha Shāsan of GōrakshaNātha. Kashmir Series of Texts and Studies, no. 20. Bombay: the Research Department of Jammu and Kashmir State/Nirnaya-Sagara Press, 1918.

Tantrasadbhāva. Mark Dyczkowski, ed. Draft edition; e-text available from the Digital Library of the Muktabodha Indological Research Institute. https://etexts.muktabod ha.org/digital_library.htm.

Tantrāloka of Abhinavagupta. Mukund Rām Shāstrī (v. 1), Madhusūdan Kaul Shāstrī (v. 2-12), eds. The Tantrāloka of Abhinava-Gupta, with Commentary by Rājānaka Jayaratha. KsTs, nos. 23, 28, 30, 36, 35, 29, 41, 47, 59, 52, 57, 58. Allahabad; Bombay: the Research Department of Jammu and Kashmir State, 1918-1938.

Nišvāsatattvasaṃhitā. Dominic Goodall, et al., eds. The Niśvāsatattvasaṃhitā. The Earliest Surviving Śaiva Tantra, volume 1. A critical edition and annotated translation of the Mülasūtra, Uttarasūtra, and Nayasūtra. Collection Indologie, no. 133 (Early Tantra Series, no. 5). Pondicherry: Pondicherry: Institut Français d'Indologie/École française d'Extrême-Orient/Universität Hamburg, 2015.

Brahmayāmala. National Archives of Kathmandu manuscript no. 3-370 (Nepal-German Manuscript Preservation Project reel no. A42/6).

Brahmayāmala. Shaman Hatley, ed. The Brahmayāmala Tantra or Picumata, volume I: Chapters 1-2, 39-40, \& 83. Revelation, Ritual, and Material Culture in an Early Śaiva Tantra. Collection Indologie, no. 128 (Early Tantra Series, no. 1). Pondicherry: Insti- 
tut Français d'Indologie/École française d'Extrême-Orient/Universität Hamburg, 2018.

Brahmayāmala. Csaba Kiss, ed. The Brahmayāmala Tantra or Picumata, volume II. The Religious Observances and Sexual Rituals of the Tantric Practitioner: Chapters 3, 21, and 45. Collection Indologie, no. 13 o (Early Tantra Series, no. 3). Pondicherry: Institut Français d'Indologie/École française d' Extrême-Orient/Universität Hamburg, 2015. Matangapārameśvara. N.R. Bhatt, ed. Matañgapārameśvarāgama (Vidyāpāda), avec le commentaire de Bhațta Rāmakaṇtha. Publications de l' Instutut français d' Indologie, no. 56. Pondicherry: Institut français d' Indologie, 1977.

Ratnatrayaparīkṣā of Śrīkaṇṭha. Vajravallabha Dvivedi, ed. Aștaprakaraṇam. Yogatantragranthamālā, no. 12. Varanasi: Sampurnanand Sanskrit University, 1988.

Sārdhatriśatikālottara. N.R. Bhatt, ed. Sārdhatriśatikālottarāgama, avec le commentaire de Bhaț̣a Rāmakaṇtha. Publications de l'Institut français d'Indologie, no. 61. Pondicherry: Institut français d'Indologie, 1979.

\section{Secondary Sources}

Hatley, Shaman. 2007. "The Brahmayāmalatantra and Early Śaiva Cult of Yoginīs." PhD dissertation, University of Pennsylvania.

Hatley, Shaman. 2018. See Brahmayāmala.

Kiss, Csaba. 2015. See Brahmayāmala.

Sanderson, Alexis. 1986. "Maṇdala and Āgamic Identity in the Trika of Kashmir." In Mantras et Diagrammes rituels dans l'Hinduisme, edited by Andre Padoux, 169-214. Paris: Editions du CNRs, 1986.

Sanderson, Alexis. 1988. "Saivism and the Tantric Traditions." In The World's Religions, edited by S. Sutherland et al., 66o-704. London: Routledge and Kegan Paul.

Tāntrikābhidhānakośa. Dictionnaire des terms techniques de la littérature hindoue tantrique. Vols. I-II. H. Brunner, G. Oberhammer, and A. Padoux, eds. Beiträge zur Kultur- und Geistesgeschichte Asiens, nos. 35 and 44. Vienna: Austrian Academy of Sciences Press, 2000 and 2004.

Tāntrikābhidhānakośa. Dictionnaire des terms techniques de la littérature hindoue tantrique. Vol. III. Dominic Goodall and Marion Rastelli, eds. Beiträge zur Kultur- und Geistesgeschichte Asiens, no. 76. Vienna: Austrian Academy of Sciences Press, 2013. 